\title{
A New Mechanism for Dansgaard-Oeschger Cycles
}

\section{Citation}

Petersen, Sierra Victoria, Daniel P. Schrag, and P. U. Clark. 2013. "A New Mechanism for Dansgaard-Oeschger Cycles." Paleoceanography 28 (1): 24-30.

\section{Published Version}

doi:10.1029/2012PA002364

\section{Permanent link}

http://nrs.harvard.edu/urn-3:HUL.InstRepos:14117051

\section{Terms of Use}

This article was downloaded from Harvard University's DASH repository, and is made available under the terms and conditions applicable to Open Access Policy Articles, as set forth at http:// nrs.harvard.edu/urn-3:HUL.InstRepos:dash.current.terms-of-use\#OAP

\section{Share Your Story}

The Harvard community has made this article openly available.

Please share how this access benefits you. Submit a story.

Accessibility 
4

$5 \quad$ A new mechanism for Dansgaard-Oeschger cycles

$8{ }^{a}$ Department of Earth and Planetary Sciences, Harvard University, Cambridge, MA

902138 USA.

$10{ }^{\mathrm{b}}$ College of Earth, Ocean, and Atmospheric Sciences, Oregon State University, Corvallis, 11 OR 97331 USA.

12 (speters@,fas.harvard.edu)

13

14 


\section{Abstract}

15 We present a new hypothesis to explain the millennial-scale temperature variability

16 recorded in ice cores known as Dansgaard-Oeschger (DO) cycles. We propose that an ice

17 shelf acted in concert with sea ice to set the slow and fast timescales of the DO cycle,

18 respectively. The abrupt warming at the onset of a cycle is caused by the rapid retreat of

19 sea ice after the collapse of an ice shelf. The gradual cooling during the subsequent

20 interstadial phase is determined by the timescale of ice-shelf regrowth. Once the ice shelf

21 reaches a critical size, sea ice expands, driving the climate rapidly back into stadial

22 conditions. The stadial phase ends when warm subsurface waters penetrate beneath the

23 ice shelf and cause it to collapse. This hypothesis explains the full shape of the DO cycle,

24 the duration of the different phases, and the transitions between them and is supported by

25 proxy records in the North Atlantic and Nordic Seas.

26 


\section{1. Introduction}

32 During the last glacial period, the North Atlantic basin experienced a number of

33 large and abrupt millennial-scale fluctuations in climate referred to as Dansgaard-

34 Oeschger (DO) cycles. Ice cores from Greenland reveal that each cycle began with an

35 abrupt warming from stadial to interstadial conditions [Johnsen et al., 1992; Dansgaard

36 et al., 1993; Grootes et al., 1993; Huber et al., 2006]. The effects of this warming

37 extended across much of the northern hemisphere [Voelker et al., 2002; Overpeck and

38 Cole, 2006; Pisias et al., 2010], while a near-simultaneous cooling occurred in Antarctica

39 [EPICA Members, 2006; Wolff et al., 2010]. Greenland ice core records then suggest

40 gradual cooling during the initial stages of each interstadial phase, followed by abrupt

41 cooling back to stadial conditions.

42 A common explanation for these cycles involves changes in the Atlantic

43 meridional overturning circulation (AMOC), perhaps triggered by freshwater forcing

44 [Clark et al., 2001; Ganopolski and Rahmstorf, 2001], but paleoceanographic evidence

45 for these changes remains elusive [Elliot et al., 2002; Piotrowski et al., 2008; Pisias et

$46 a l ., 2010]$. Here we propose a mechanism to explain these millennial-scale climate cycles

47 involving abrupt changes in sea-ice cover, gradual regrowth of ice shelves, and warming

48 of intermediate-depth waters.

50 2. Rapid Climate Change in Greenland Ice Cores

$51 \quad \delta^{18} \mathrm{O}$ records from Greenland ice cores show that each DO cycle began with an

52 abrupt shift in $\delta^{18} \mathrm{O}_{\text {ice}}$, occurring in as little as a few years [Steffensen et al., 2008;

53 Thomas et al., 2009], which was associated with a large warming, ranging from $8^{\circ} \mathrm{C}$ to 
$5416^{\circ} \mathrm{C}[$ Severinghaus et al., 1998; Huber et al., 2006; Wolff et al., 2010 and references

55 therein]. Other properties of the ice, including electrical conductivity [Taylor et al.,

56 1993a, 1993b], deuterium-excess [Dansgaard et al., 1989, Steffensen et al., 2008], dust

57 content [Fuhrer et al., 1999], and methane concentrations [Brook et al., 1996] changed in

58 less than a decade. At the same time, accumulation rates roughly doubled and

59 proportionally more precipitation fell in winter months [Alley et al., 1993; Cuffey and

60 Clow, 1997].

61 Following the abrupt warming, the interstadial climate gradually cooled before

62 abruptly cooling back to stadial conditions. A stable stadial climate characterized by low

$63 \delta^{18} \mathrm{O}_{\text {ice }}$ values was then maintained for the next hundreds to thousands of years until the

64 next abrupt warming, concluding the DO cycle. This characteristic trapezoid shape in

$65 \delta^{18} \mathrm{O}_{\text {ice }}$ can be seen for all DO cycles, but their duration varies from $\sim 1.1$ to $8.6 \mathrm{kyr}$

66 (Figure 1A) [Andersen et al., 2006]. Grootes and Stuiver [1997] found a strong peak at

671470 years in the power spectrum of DO cycles 1 through 13, but Schulz [2002] showed

68 that most of the power in the 1470-year band came from DO cycles 5-7 only. Due to

69 varying age models and statistical techniques, debate persists over whether a 1470-year

70 periodicity exists in the DO time series [Wunsch, 2000; Rahmstorf, 2003; Ditlevsen et al.,

71 2007]. Based on multiple proxy records with DO-like cycles, Pisias et al. [2010] found a

72 mode of variability with broad spectral power of $\sim 1600$ years rather than a sharp spectral

73 peak at 1470 years.

74 Many climate proxies around the globe show DO-like variability on similar time

75 scales. Proxies from the northern hemisphere show warmer (colder) and wetter (drier)

76 climates during DO interstadials (stadials) [Voelker et al., 2002; Overpeck and Cole, 
77 2006; Pisias et al., 2010]. In the Antarctic EDML ice core, there is an inverse relation

78 between northern and southern hemisphere climate oscillations (bi-polar seesaw), with a

79 correlation between Greenland stadial duration and the amplitude of the Antarctic

80 temperature warming [EPICA Members, 2006].

81 Sediment cores from $40-50^{\circ} \mathrm{N}$ in the North Atlantic (the so-called ice rafted debris

82 (IRD) belt) show IRD from Icelandic and European sources associated with every DO

83 stadial [Bond and Lotti, 1995], but are dominated by larger IRD pulses from the

84 Laurentide ice sheet known as Heinrich events, associated with only every second to

85 fourth stadial (Figure 1A, 1C) [Hemming, 2004 and references therein]. In contrast, in the

86 Nordic Seas [Voelker et al., 1998; Dokken and Jansen, 1999] and the Irminger Basin [van

87 Kreveld et al., 2000; Elliot et al., 2001], IRD pulses of roughly equal magnitude are

88 visible for every DO stadial, while characteristic Heinrich layers are absent (Figure 1B).

89 Planktonic $\delta^{18} \mathrm{O}$ records show large negative excursions associated with Heinrich events

90 in both the Nordic Seas (Figure 1B) [Voelker et al., 1998; Rasmussen et al., 1996; Elliot

91 et al., 1998; van Kreveld et al., 2000] and the IRD belt (Figure 1C) [Bond et al., 1992;

92 Hillaire-Marcel and Bilodeau, 2000; Hemming, 2004 and references therein], but in the

93 Nordic Seas, weaker negative spikes are also visible for the non-Heinrich stadials (Figure

94 1B).

95

\section{3. Previous Hypotheses for DO cycles}

97 The origin of DO cycles has commonly been explained by changes in the AMOC,

98 but a mechanism for forcing the AMOC at this timescale remains unknown and existing

99 proxy data do not show corresponding changes in the AMOC for every DO cycle. Winton 
100 [1993] showed that rapid increases in the overturning rate ("flushing" events) could be

101 produced periodically in models by including a constant atmospheric transport of

102 freshwater from low to high latitudes. This mechanism operates on millennial time scales

103 without the need to dictate a periodicity. The magnitude of warming produced by

104 oscillations of the AMOC alone, however, was substantially less than the warming

105 reconstructed over Greenland during DO events [Huber et al., 2006].

106 Ganopolski and Rahmstorf [2001] produced a time series of characteristically-

107 shaped DO cycles by forcing an intermediate complexity model with a sinusoidal

108 freshwater flux with a period of 1470 years, which caused large reductions and

109 subsequent resumptions in AMOC strength that resulted in temperature changes over

110 Greenland. We note, however, that there is no known physical mechanism to explain

111 such a sinusoidal fluctuation in the hydrological cycle. Moreover, despite what are likely

112 unrealistically high rates of overturning $(\sim 50 \mathrm{~Sv})$ reached by this model, the simulated

113 warming was again considerably less than the reconstructed Greenland temperatures

114 [Huber et al., 2006].

115 Although benthic $\delta^{13} \mathrm{C}$ [Zahn et al., 1997; Shackleton et al., 2000; Elliot et al.,

116 2002] and neodymium [Piotrowski et al., 2008; Gutjahr et al., 2010] records from

117 intermediate and deep Atlantic sites indicate substantial changes in the AMOC during

118 DO stadials associated with Heinrich events, no significant changes are seen during non-

119 Heinrich stadials. This indicates that large changes in the AMOC could not have been the 120 primary mechanism behind all the DO cycles.

121 An alternative mechanism for causing abrupt DO warming involves changes in

122 sea-ice cover [Li et al., 2005; Gildor and Tziperman, 2003]. By removing winter sea-ice 
123 cover over a large part of the North Atlantic, Li et al. [2005] simulated an annual average

124 warming of up to $5-7^{\circ} \mathrm{C}$ over Greenland, consistent with the lower end of DO warming

125 reconstructed from $\delta^{15} \mathrm{~N}$ of gases trapped in the ice [Huber et al., 2006]. In addition, the

126 simulation produced a doubling of accumulation rate and a shift to more wintertime

127 precipitation, also in agreement with observations from ice cores [Alley et al., 1993;

128 Cuffey and Clow, 1997; Svensson et al., 2008]. Li et al. [2010] also found that a reduction

129 in sea-ice cover in the Nordic Seas alone produced significantly more warming

130 (especially in winter) over Greenland's summit than removing sea-ice cover in the

131 western and central North Atlantic, suggesting that the Nordic Sea region may be critical

132 in terms of influencing the air temperature over Greenland.

133 Li et al. [2010] proposed that rapid sea-ice retreat from the Nordic Seas, possibly

134 in response to small changes in wind stress or heat transport, could explain the rapid

135 warming at the onset of a DO cycle. However, this same property of sea ice cannot

136 explain much of the remainder of the DO cycle, which includes the intervals of gradual

137 cooling during the interstadial phase and the sustained cold stadial climate, each of which

138 lasted hundreds of years. This suggests that some other mechanism is needed to set these

139 longer timescales in the DO cycle.

140

141 4. A Hypothesis for DO Cycles

142 We propose a conceptual model for DO cycles that explains their characteristic

143 temporal evolution and is supported by existing proxies of ice-sheet, climate and AMOC

144 variability. In particular, we adopt the sea-ice mechanism of Li et al. [2005; 2010] to

145 explain the fast-changing intervals of the DO cycles (Figure 2b, 2d). We then invoke an 
146 ice shelf to explain the slower-changing phases of the DO cycles (Figure 2a, 2c). From

147 the perspective of the atmosphere, an ice shelf looks the same as sea ice in terms of its

148 albedo and its insulating effects, which reduce the release of heat from the ocean.

149 However, because ice shelves are much thicker than sea ice $(100$ s of m vs. $<10 \mathrm{~m})$, they

150 are largely insensitive to small changes in heat transport or wind stress.

151 We first consider the influence of an ice shelf covering a large region of the ocean

152 east of Greenland in the Nordic Seas. Given the sensitivity analysis by Li et al. [2010]

153 and the number of proxies showing variability of the cryosphere on DO timescales in the

154 Nordic Seas (e.g. Figure 1B and others) [Voelker et al., 1998; Rasmussen et al., 1996;

155 Elliot et al., 2002; Dokken and Jansen, 1999], we focus on an ice shelf along the eastern

156 Greenland margin that could influence sea-ice cover in this region. We propose that the

157 cooling effect of a large ice shelf combined with extensive sea-ice cover would result in

158 regionally cold surface temperatures due to the insulating properties of the ice shelf and

159 sea ice, as well as their effect on local albedo [Li et al., 2005; 2010]. This stadial climate

160 would be maintained for as long as the ice shelf was present.

161 In the event of the ice shelf's collapse, potentially caused by warming of

162 subsurface waters (discussed below), the only remaining ice cover would be sea ice and

163 floating icebergs. A small change in wind stress or heat transport could quickly export or

164 melt this ice, resulting in a large increase in open-ocean area and a corresponding large

165 and abrupt warming over Greenland marking the start of a new DO cycle [Li et al., 2005;

$1662010]$.

167 During the interstadial phase of a DO cycle, the near doubling of accumulation

168 over the Greenland Ice Sheet that accompanies the warmer climate [Alley et al., 1993; 
169 Cuffey and Clow, 1997; Svensson et al., 2008] would induce a more positive mass

170 balance, causing the ice shelf to begin reforming along the coast. Expansion of the ice

171 shelf to cover increasingly more ocean surface area would cause air temperatures to

172 gradually cool over Greenland. Once the shelf reached a critical size, it would cause sea

173 ice to rapidly expand through the sea-ice-albedo feedback [Gildor and Tziperman, 2003],

174 driving climate back to stadial conditions and completing the DO cycle. The same cycle

175 could not be achieved with multi-year sea ice because its regrowth timescale is

176 inconsistent with the gradual decline of climate over the duration of the interstadial

177 phase.

178 In summary, our hypothesis combines the ability of sea ice in the Nordic Seas to

179 explain the rapid transition into and out of the interstadial phase [Li et al., 2010] with a

180 gradually expanding ice shelf derived from eastern Greenland to (i) explain the

181 progressive cooling during the interstadial (Figure 2c), (ii) provide the mechanism to

182 trigger sea-ice growth to cause the rapid cooling (Figure 2d), and (iii) sustain the stadial

183 climate once the ice shelf reaches steady state (Figure 2a, 2e). The duration of the

184 interstadial phase is determined by the time required to regrow the ice shelf to a threshold

185 size, beyond which the local ice-albedo effect causes the rapid expansion of sea ice and

186 the corresponding switch to a stadial climate. After a time, ice-shelf collapse, potentially

187 due to subsurface warming, along with an associated rapid loss of sea ice causes the 188 abrupt warming that starts a new DO cycle.

189

190 5. Discussion 
We summarize here proxy records, model results, and modern observations that

192 support key elements of our hypothesis for DO cycles. Multiple lines of evidence support

193 the presence of ice shelves in the northern high latitudes during the last glaciation.

194 Reconstructions of seawater salinity during the LGM show that the ocean was saltier than 195 expected from ice-sheet build-up alone [Adkins et al., 2002]. Reconciling these

196 observations requires either a large change in the volume of groundwater or additional ice 197 shelves equivalent to seven times the volume of the modern Antarctic ice shelves [Adkins 198 et al., 2002]. In addition, there is widespread evidence on the continental shelves

199 surrounding the Nordic Seas, including off eastern Greenland, of fast-flowing ice

200 extending to the shelf edge that may have fed ice shelves [Vorren et al., 1998; Stokes and

201 Clark, 2001; Svendsen et al., 2004; Evans et al., 2009; Dowdeswell et al., 2010].

202 Proxy records suggest substantial variability of the cryosphere in the Nordic Seas

203 on DO timescales. IRD records and planktonic $\delta^{18} \mathrm{O}$ anomalies in the Nordic Seas

204 [Voelker et al., 1998; Dokken and Jansen, 1999] and in the Irminger Basin [van Kreveld

205 et al., 2000; Elliot et al., 1998, 2001] suggest an increase in ice-rafting during each DO

206 stadial (Figure 1B). As discussed previously, these records showing similar-scale

207 variability for every DO stadial differ from those found further south in the IRD belt,

208 where the most prominent IRD and $\delta^{18} \mathrm{O}$ signals are associated with Heinrich events

209 derived from the Laurentide Ice Sheet, and the signals during non-Heinrich DO stadials,

210 particularly in $\delta^{18} \mathrm{O}$, are weak to absent (Figure 1C) [Bond et al., 1992; Cortijo et al.,

211 1997; Labeyrie et al., 1999; Hillaire-Marcel and Bilodeau, 2000].

212 An ice shelf constricting the Denmark Strait between Greenland and Iceland may 213 have played an important additional role in influencing sea-ice cover in the Nordic Seas. 
214 Firstly, proxies of ice rafting in this area show a strong response on DO timescales

215 (Figure 1B) [Voelker et al., 1998]. Additionally, during the glaciation, grounded ice

216 extended to the shelf break from both Greenland [Vorren et al., 1998; Dowdeswell et al.,

217 2010] and Iceland [Hubbard et al., 2006], narrowing the strait to a width of only 150

$218 \mathrm{~km}$ [Kosters et al., 2004]. Today, the East Greenland Current passes south through the

219 Denmark Strait and exports substantial sea ice from the Arctic to the North Atlantic. If an

220 ice shelf restricted this outlet, which is an ideal setting for growing an ice shelf due to

221 its shallow shelf bathymetry and proximity to two coastlines, sea-ice export would

222 likely be impeded. A "log jam" of sea ice could build up north of the Denmark Strait,

223 contributing to further sea-ice expansion through the ice-albedo feedback. The removal of

224 the ice shelf would allow the East Greenland Current to resume, increasing sea-ice export

225 southward into the mid-North Atlantic. In this way, the ice shelf could indirectly

226 influence ice cover over a larger area of ocean.

227 Previously, Hulbe et al. [2004] proposed a similar mechanism involving the

228 destruction of an ice shelf in the Labrador Sea to explain Heinrich events, but this

229 hypothesis failed to explain why the ice shelf would collapse only during the cold stadial

230 phases [Alley et al., 2005]. Shaffer et al. [2004] explained this relationship by suggesting

231 that warming of intermediate-depth waters associated with a large reduction in the

232 AMOC, such as that which occurred prior to Heinrich events [Zahn et al., 1997; Clark et

233 al., 2007; Piotrowski et al., 2008; Pisias et al., 2010; Gutjahr et al., 2010], would cause

234 melting of the Hudson Strait ice shelf from below while surface temperatures remained

235 cold. Additional model results and proxy data provide support for this mechanism 
236 [Rasmussen et al., 2003; Clark et al., 2007; Alvarez-Solas et al., 2010, 2011; Marcott et 237 al., 2011].

238 Similarly, we propose that subsurface warming caused the collapse of the

239 hypothesized ice shelf along the eastern Greenland margin. In the Nordic Seas,

240 Rasmussen and Thomsen [2004] found changes in benthic fauna that suggest intrusion of

241 warm intermediate waters during stadial phases of DO cycles [Rasmussen et al., 1996;

242 Rasmussen and Thomsen, 2004]. Depleted benthic $\delta^{18} \mathrm{O}$ signals during DO stadials in this

243 region are also consistent with warming of intermediate depth waters [Rasmussen et al.,

244 1996; Dokken and Jansen, 1999; Rasmussen and Thomsen, 2004], with a dominant

245 temperature control on these signals supported by $\mathrm{Mg} / \mathrm{Ca}$ measurements [Jonkers et al, 246 2010; Marcott et al., 2011].

247 Several lines of evidence identify subsurface warming as an effective way to 248 destabilize an ice shelf from below. Modern observations show that warm waters at the 249 base of the ice tongue in front of Jakobshavn Isabrae in western Greenland [Holland et $250 a l ., 2008$ ] and an ice shelf in front of Pine Island glacier in Antarctica [Jenkins et al., 251 2010] increased basal melting, causing thinning, retreat, and destabilization of those ice 252 shelves, leading to accelerated ice discharge. Ice shelf-ice stream models forced by 253 subsurface warming produce similar results [Walker et al., 2009; Joughin et al., 2010]. 254 In climate model simulations, warming of intermediate waters in the North 255 Atlantic basin is a robust response to a large reduction in the AMOC [Knutti et al., 2004; 256 Clark et al., 2007; Mignot et al., 2007; Liu et al., 2009; Brady and Otto-Bliesner, 2011].

257 However, model runs show that subsurface warming can still develop with relatively 258 modest changes in the AMOC [Brady and Otto-Bliesner, 2011; Mahajan et al., 2011] and 
259 is accompanied by a southward shift in the site of convection [Brady and Otto-Bliesner,

$2602011]$. In the context of our hypothesis, expansion of the ice shelf as well as increased

261 freshwater fluxes from iceberg calving and melting of sea ice transported southward may

262 have caused a slight reduction in the AMOC and a southward shift in convection, causing

263 subsurface warming to develop locally under the expanded ice shelf fringing Greenland

264 in the Nordic Seas. A decrease in flushing by the AMOC around the ice shelf may have

265 allowed the build-up of atmospherically-derived freshwater in the surface ocean that, in

266 addition to the melting of isotopically depleted icebergs calved off the ice shelf, could

267 have contributed to the light planktonic $\delta^{18} \mathrm{O}$ observed in the region during stadials.

268 During the LGM, the sea ice edge could have been too far south for the subsurface

269 warming to penetrate beneath the ice shelf, resulting in no DO events except

270 following Heinrich events when the amount and extent of subsurface warming was

271 greater.

272 Although proxy evidence indicates that large reductions in AMOC strength only

273 occurred during Heinrich stadials [Zahn et al., 1997; Clark et al., 2007; Piotrowski et al.,

274 2008; Pisias et al., 2010], existing ocean proxies may not be sensitive to the modest

275 AMOC reductions that models suggest can still induce subsurface warming. Antarctic ice

276 cores show warming events corresponding to the Heinrich stadials [EPICA Members,

277 2006], times when the AMOC was significantly reduced and interhemispheric heat

278 transport was weaker. Between these larger Antarctic warming events, smaller events

279 have been correlated with the non-Heinrich stadials [Wolff et al., 2010], consistent with

280 minor changes in heat transport (and therefore AMOC strength) during these times. 
Proxies outside of the Atlantic hint at global changes in intermediate depth

282 circulation occurring during DO stadials prior to the abrupt warming. High-resolution

283 sediment cores from the Santa Barbara basin show decreases in benthic $\delta^{18} \mathrm{O}$ occurring

$28460-200$ years prior to the abrupt decrease in planktonic $\delta^{18} \mathrm{O}$ representing the surface

285 warming of the DO event [Hendy and Kennett, 2003]. This phasing was interpreted as a

286 shift in intermediate depth circulation bringing $\delta^{18} \mathrm{O}$-depleted water from the north

287 Pacific into the basin prior to the large-scale atmospheric reorganizing accompanying the

288 DO event warmed the surface waters [Hendy and Kennett, 2003]. In addition, high-

289 resolution ice core studies show that atmospheric $\mathrm{N}_{2} \mathrm{O}$ began to rise prior to the rapid DO

290 warmings [Flückiger et al., 2004]. In models, global atmospheric $\mathrm{N}_{2} \mathrm{O}$ production,

291 predominantly from the tropical Pacific, has been shown to vary as a result of changes in

292 the AMOC [Schmittner and Galbraith, 2008], suggesting the early rise in atmospheric

$293 \mathrm{~N}_{2} \mathrm{O}$ observed in ice cores could be an indicator of changes in Pacific and Atlantic ocean

294 circulations at intermediate depths prior to the main DO event.

295

296 6. Conclusion

297 We describe a new mechanism to explain DO cycles involving the formation and 298 collapse of an ice shelf fringing eastern Greenland, potentially extending across the

299 Denmark Strait. Our hypothesis explains the rapid transitions into and out of the

300 interstadial using the ability of sea ice to rapidly expand and contract, whereas the

301 slower-changing phases are explained by the presence or absence of an ice shelf. The

302 duration of the interstadial phase is set by the regrowth timescale of the ice shelf, and the 303 duration of the stadial phase is determined by the timing of ice-shelf removal, potentially 
304 due to subsurface warming. Existing proxy evidence from the Nordic Seas supports the

305 idea of fluctuating ice volume in the region in time with DO cycles. Further proxy studies

306 could explore the IRD and meltwater fluxes resulting from such an ice-shelf break up.

307 Modeling work using an active sea-ice model could test the response of sea ice to the

308 presence or absence of an ice shelf fringing eastern Greenland. A combination of these

309 and other approaches can test the feasibility of this idea and illuminate the exact location

310 of the proposed ice shelf.

311

\section{Acknowledgements}

313 SVP and DPS were supported by the NSF Marine Geology and Geophysics Program

314 through grant OCE-0961372. PUC was supported by the NSF Paleoclimate Program

315 for the Paleovar Project through grant AGS-0602395 and by the Harvard University

316 Center for the Environment. The authors thank Eli Tziperman, David Battisti, Chris

317 Charles, and Jeff Severinghaus for helpful comments and suggestions.

\section{References}

320 Adkins, J. F., K. McIntyre, and D. P. Schrag (2002), The salinity, temperature, and $\delta^{18} \mathrm{O}$

321 of the glacial deep ocean, Science, 298(5599), 1769-1773,

322 doi:10.1126/science.1076252.

323 Alley, R. B., J. T. Andrews, D. C. Barber and P. U. Clark (2005), Comment on

324 "Catastrophic ice shelf breakup as the source of Heinrich event icebergs" by C. L.

325 Hulbe et al, Paleoceanography, 20(1), PA1009, doi:10.1029/2004pa001086. 
326 Alley, R. B., D. A. Meese, C. A. Shuman, A. J. Gow, K. C. Taylor, P. M. Grootes, J. W.

327 C. White, M. Ram, E. D. Waddington, P. A. Mayewski and G. A. Zielinski (1993),

328 Abrupt increase in Greenland snow accumulation at the end of the Younger Dryas

329 event, Nature, 362(6420), 527-529, doi:10.1038/362527a0.

330 Alvarez-Solas, J., S. Charbit, C. Ritz, D. Paillard, G. Ramstein and C. Dumas (2010),

331 Links between ocean temperature and iceberg discharge during Heinrich events, Nat.

332 Geosci., 3(2), 122-126, doi:10.1038/ngeo752.

333 Alvarez-Solas, J., M. Montoya, C. Ritz, G. Ramstein, S. Charbit, C. Dumas, K.

334 Nisancioglu, T. Dokken and A. Ganopolski (2011), Heinrich event 1: an example of

335 dynamical ice-sheet reaction to oceanic changes, Clim. Past, 7(4), 1297-1306,

336 doi:10.5194/cp-7-1297-2011.

337 Andersen, K. K., A. Svensson, S. J. Johnsen, S. O. Rasmussen, M. Bigler, R.

338 Röthlisberger, U. Ruth, M.-L. Siggaard-Andersen, J. R. Peder Steffensen, D. Dahl-

339 Jensen, B. M. Vinther and H. B. Clausen (2006), The Greenland Ice Core Chronology

340 2005, 15-42ka. Part 1: constructing the time scale, Quat. Sci. Rev., 25(23-24), 3246-

$341 \quad 3257$, doi:10.1016/j.quascirev.2006.08.002.

342 Bond, G., H. Heinrich, W. Broecker, L. Labeyrie, J. McManus, J. Andrews, S. Huon, R.

343 Jantschik, S. Clasen, C. Simet, K. Tedesco, M. Klas, G. Bonani and S. Ivy (1992),

344 Evidence for massive discharges of icebergs into the North Atlantic ocean during the

345 last glacial period, Nature, 360(6401), 245-249.

346 Bond, G. C., and R. Lotti (1995), Iceberg Discharges into the North Atlantic on

347 Millennial Time Scales During the Last Glaciation, Science, 267(5200), 1005-1010,

348 doi:10.1126/science.267.5200.1005. 
349 Brady, E., and B. Otto-Bliesner (2011), The role of meltwater-induced subsurface ocean

350 warming in regulating the Atlantic meridional overturning in glacial climate

351 simulations, Clim. Dyn., 37(7), 1517-1532, doi:10.1007/s00382-010-0925-9.

352 Brook, E. J., T. Sowers and J. Orchardo (1996), Rapid Variations in Atmospheric

353 Methane Concentration During the Past 110,000 Years, Science, 273(5278), 1087-

$354 \quad$ 1091, doi:10.1126/science.273.5278.1087.

355 Clark, P. U., S. W. Hostetler, N. G. Pisias, A. Schmittner and K. J. Meissner (2007),

356 Mechanisms for an 7-kyr Climate and Sea-Level Oscillation During Marine Isotope

357 Stage 3, in Ocean Circulation: Mechanisms and Impacts, Geophys. Monogr. Ser.,

358 vol. 173, edited by A. Schmittner, J. Chiang, and S. Hemming, pp. 209-246, AGU,

359 Washington, D.C. doi:10.1029/173GM15.

360 Clark, P. U., S. J. Marshall, G. K. C. Clarke, S. W. Hostetler, J. M. Licciardi and J. T.

361 Teller (2001), Freshwater Forcing of Abrupt Climate Change During the Last

362 Glaciation, Science, 293(5528), 283-287, doi:10.1126/science.1062517.

363 Cortijo, E., L. Labeyrie, L. Vidal, M. Vautravers, M. Chapman, J.-C. Duplessy, M. Elliot,

364 M. Arnold, J.-L. Turon and G. Auffret (1997), Changes in sea surface hydrology

365 associated with Heinrich event 4 in the North Atlantic Ocean between $40^{\circ}$ and $60^{\circ} \mathrm{N}$,

366 Earth Planet. Sci. Lett., 146(1-2), 29-45, doi:10.1016/S0012-821X(96)00217-8.

367 Cuffey, K. M., and G. D. Clow (1997), Temperature, accumulation, and ice sheet

368 elevation in central Greenland through the last deglacial transition, J. Geophys. Res.,

369 102(C12), 26383-26396, doi:10.1029/96jc03981.

370 Dansgaard, W., S. J. Johnsen, H. B. Claussen, D. Dahl-Jensen, N. S. Gundestrup, C. U.

371 Hammer, C. S. Hvidberg, J. P. Steffensen, A. Sveinbjörnsdóttir, J. Jouzel and G. 
372 Bond (1993), Evidence for general instability of past climate from a 250-kyr ice-core

373 record, Nature, 364, 218-220, doi:10.1038/364218a0.

374 Dansgaard, W., J. W. C. White and S. J. Johnsen (1989), The Abrupt Termination of the

$375 \quad$ Younger Dryas Climate Event, Nature, 339(6225), 532-534.

376 Ditlevsen, P. D., K. K. Andersen and A. Svensson (2007), The DO-climate events are

377 probably noise induced: statistical investigation of the claimed 1470 years cycle,

$378 \quad$ Clim. Past, 3(1), 129-134, doi:10.5194/cp-3-129-2007.

379 Dokken, T. M., and E. Jansen (1999), Rapid changes in the mechanism of ocean

380 convection during the last glacial period, Nature, 401(6752), 458-461,

381 doi: $10.1038 / 46753$.

382 Dowdeswell, J. A., J. Evans and C. O Cofaigh (2010), Submarine landforms and shallow

383 acoustic stratigraphy of a $400 \mathrm{~km}$-long fjord-shelf-slope-transect, Kangerlussuaq

384 margin, East Greenland., Quat. Sci. Rev., 29(25-26), 3359-3369,

385 doi:10.1016/j.quascirev.2010.06.006.

386 Elliot, M., L. Labeyrie, T. Dokken and S. Manthé (2001), Coherent patterns of ice-rafted 387 debris deposits in the Nordic regions during the last glacial (10-60 ka), Earth Planet. 388 Sci. Lett., 194(1-2), 151-163, doi:10.1016/S0012-821X(01)00561-1.

389 Elliot, M., L. Labeyrie, G. Bond, E. Cortijo, J.-L. Turon, N. Tisnerat and J.-C. Duplessy 390 (1998), Millennial-Scale Iceberg Discharges in the Irminger Basin During the Last 391 Glacial Period: Relationship with the Heinrich Events and Environmental Settings, 392 Paleoceanography, 13(5), 433-446, doi:10.1029/98pa01792. 
393 Elliot, M., L. Labeyrie and J.-C. Duplessy (2002), Changes in North Atlantic deep-water

394 formation associated with the Dansgaard-Oeschger temperature oscillations (60-

395 10ka), Quat. Sci. Rev., 21(10), 1153-1165, doi:10.1016/S0277-3791(01)00137-8.

396 EPICA Members (2006), One-to-one coupling of glacial climate variability in Greenland

397 and Antarctica, Nature, 444, 195-198, doi:10.1038/nature05301.

398 Evans, J., C. Ó Cofaigh, J. A. Dowdeswell and P. Wadhams (2009), Marine geophysical

399 evidence for former expansion and flow of the Greenland Ice Sheet across the north-

400 east Greenland continental shelf, J. Quat. Sci., 24(3), 279-293, doi:10.1002/jqs.1231.

401 Flückiger, J., T. Blunier, B. Stauffer, J. Chappellaz, R. Spahni, K. Kawamura, J.

402 Schwander, T. F. Stocker and D. Dahl-Jensen (2004), $\mathrm{N}_{2} \mathrm{O}$ and $\mathrm{CH}_{4}$ variations during

403 the last glacial epoch: Insight into global processes, Global Biogeochem. Cycles,

404 18(1), GB1020, doi: 10.1029/2003gb002122.

405 Fuhrer, K., E. W. Wolff and S. J. Johnsen (1999), Timescales for dust variability in the

406 Greenland Ice Core Project (GRIP) ice core in the last 100,000 years, J. Geophys.

407 Res., 104(D24), 31043-31052, doi:10.1029/1999jd900929.

408 Ganopolski, A., and S. Rahmstorf (2001), Rapid changes of glacial climate simulated in a 409 coupled climate model, Nature, 409(6817), 153-158, doi:10.1038/35051500.

410 Gildor, H., and E. Tziperman (2003), Sea-Ice Switches and Abrupt Climate Change,

411 Philos. Trans. R. Soc. London, Ser. A, 361(1810), 1935-1944.

412 Grootes, P. M., and M. Stuiver (1997), Oxygen 18/16 variability in Greenland snow and

413 ice with $10^{\wedge} 3$ - to $10^{\wedge} 5$-year time resolution, J. Geophys. Res., 102(C12), 26455-

$414 \quad 26470$, doi:10.1029/97jc00880. 
415 Grootes, P. M., M. Stuiver, J. W. C. White, S. Johnsen and J. Jouzel (1993), Comparison

416 of oxygen isotope records from the GISP2 and GRIP Greenland ice cores, Nature,

417 366(6455), 552-554, doi:10.1038/366552a0.

418 Gutjahr, M., B. A. A. Hoogakker, M. Frank and I. N. McCave (2010), Changes in North

419 Atlantic Deep Water strength and bottom water masses during Marine Isotope Stage 3

420 (45-35 ka BP), Quat. Sci. Rev., 29(19-20), 2451-2461,

421 doi:10.1016/j.quascirev.2010.02.024.

422 Hemming, S. R. (2004), Heinrich events: Massive late Pleistocene detritus layers of the

423 North Atlantic and their global climate imprint, Rev. Geophys., 42(1), RG1005, 424 doi:10.1029/2003rg000128.

425 Hendy, I. L., and J. P. Kennett (2003), Tropical forcing of North Pacific intermediate 426 water distribution during Late Quaternary rapid climate change?, Quat. Sci. Rev., 427 22(5-7), 673-689, doi:10.1016/S0277-3791(02)00186-5.

428 Hillaire-Marcel, C., and G. Bilodeau (2000), Instabilities in the Labrador Sea water mass 429 structure during the last climatic cycle, Can. J. Earth Sci., 37(5), 795-809, $430 \quad$ doi:10.1139/cjes-37-5-795.

431 Holland, D. M., R. H. Thomas, B. De Young, M. H. Ribergaard and B. Lyberth (2008), 432 Acceleration of Jakobshavn Isbrae triggered by warm subsurface ocean waters, Nat. 433 Geosci., 1(10), 659-664, doi:10.1038/ngeo316.

434 Hubbard, A., D. Sugden, A. Dugmore, H. Norddahl and H. r. G. Pétursson (2006), A 435 modelling insight into the Icelandic Last Glacial Maximum ice sheet, Quat. Sci. Rev., 436 25(17-18), 2283-2296, doi:10.1016/j.quascirev.2006.04.001.

437 Huber, C., M. Leuenberger, R. Spahni, J. Flückiger, J. Schwander, T. F. Stocker, S. 
438

439

440

441

442

443

444

445

446

447

448

449

450

451

452

453

454

455

456

457

458

459

460

Johnsen, A. Landais and J. Jouzel (2006), Isotope calibrated Greenland temperature record over Marine Isotope Stage 3 and its relation to CH4, Earth Planet. Sci. Lett., 243(3-4), 504-519, doi:10.1016/j.eps1.2006.01.002.

Hulbe, C. L., D. R. MacAyeal, G. H. Denton, J. Kleman and T. V. Lowell (2004), Catastrophic ice shelf breakup as the source of Heinrich event icebergs, Paleoceanography, 19(1), PA1004, doi:10.1029/2003pa000890.

Jenkins, A., P. Dutrieux, S. S. Jacobs, S. D. McPhail, J. R. Perrett, A. T. Webb and D. White (2010), Observations beneath Pine Island Glacier in West Antarctica and implications for its retreat, Nat. Geosci., 3(7), 468-472, doi:10.1038/ngeo890.

Johnsen, S. J., H. B. Clausen, W. Dansgaard, K. Fuhrer, N. Gundestrup, C. U. Hammer, P. Iversen, J. Jouzel, B. Stauffer and J. P. Steffensen (1992), Irregular glacial interstadials recorded in a new Greenland ice core, Nature, 359(6393), 311-313, doi:10.1038/359311a0.

Jonkers, L., M. Moros, M. A. Prins, T. Dokken, C. A. Dahl, N. Dijkstra, K. Perner and G.-J. A. Brummer (2010), A reconstruction of sea surface warming in the northern North Atlantic during MIS 3 ice-rafting events, Quat. Sci. Rev., 29(15-16), 17911800, doi:10.1016/j.quascirev.2010.03.014.

Joughin, I., B. E. Smith and D. M. Holland (2010), Sensitivity of 21 st century sea level to ocean-induced thinning of Pine Island Glacier, Antarctica, Geophys. Res. Lett., 37(20), L20502, doi:10.1029/2010g1044819.

Knutti, R., J. Flückiger, T. F. Stocker and A. Timmermann (2004), Strong hemispheric coupling of glacial climate through freshwater discharge and ocean circulation, Nature, 430(7002), 851-856, doi:10.1038/nature02786. 
461 Kosters, F., R. Kase, K. Fleming and D. Wolf (2004), Denmark Strait overflow for Last

462 Glacial Maximum to Holocene conditions, Paleoceanography, 19(2), PA2019, 463 doi:10.1029/2003pa000972.

464 Labeyrie, L., H. Leclaire, C. Waelbroeck, E. Cortijo, J.-C. Duplessy, L. Vidal, M. Elliot, 465 B. Le Coat (1999), Temporal Variability of the Surface and Deep Waters of the North 466 West Atlantic Ocean at Orbital and Millennial Scales, in Mechanisms of Global 467 Climate Change at Millennial Time Scales, Geophys. Monogr. Ser., vol. 112, edited 468 by P.U. Clark, R.S. Webb, and L.D. Keigwin, p. 77-98, AGU, Washington, D.C. 469 Li, C., D. S. Battisti and C. M. Bitz (2010), Can North Atlantic Sea Ice Anomalies 470 Account for Dansgaard-Oeschger Climate Signals?, J. Clim., 23(20), 5457-5475, 471 doi:10.1175/2010JCLI3409.1.

472 Li, C., D. S. Battisti, D. P. Schrag and E. Tziperman (2005), Abrupt climate shifts in 473 Greenland due to displacements of the sea ice edge, Geophys. Res. Lett., 32(19), $474 \quad$ L19702, doi:10.1029/2005g1023492.

475 Liu, Z., B. L. Otto-Bliesner, F. He, E. C. Brady, R. Tomas, P. U. Clark, A. E. Carlson, J. 476 Lynch-Stieglitz, W. Curry, E. Brook, D. Erickson, R. Jacob, J. Kutzbach and J. Cheng 477 (2009), Transient Simulation of Last Deglaciation with a New Mechanism for 478 Bølling-Allerød Warming, Science, 325(5938), 310-314, 479 doi:10.1126/science.1171041.

480 Mahajan, S., R. Zhang, T. L. Delworth, S. Zhang, A. J. Rosati and Y.-S. Chang (2011), 481 Predicting Atlantic meridional overturning circulation (AMOC) variations using 482 subsurface and surface fingerprints, Deep Sea Res., Part II, 58(17-18), 1895-1903, 483 doi:10.1016/j.dsr2.2010.10.067. 
484 Marcott, S. A., P. U. Clark, L. Padman, G. P. Klinkhammer, S. R. Springer, Z. Liu, B. L.

485 Otto-Bliesner, A. E. Carlson, A. Ungerer, J. Padman, F. He, J. Cheng and A.

486 Schmittner (2011), Ice-shelf collapse from subsurface warming as a trigger for

487 Heinrich events, PNAS, 108(33), 13415-13419, doi:10.1073/pnas.1104772108.

488 Mignot, J., A. Ganopolski and A. Levermann (2007), Atlantic subsurface temperatures:

489 Response to a shutdown of the overturning circulation and consequences for its

$490 \quad$ recovery, J. Clim., 20(19), 4884-4898, doi:10.1175/jcli4280.1.

491 Overpeck, J. T., and J. E. Cole (2006), Abrupt Change in Earth's Climate System, Annu.

492 Rev. Environ. Resour., 31(1), 1-31, doi:10.1146/annurev.energy.30.050504.144308.

493 Piotrowski, A. M., S. L. Goldstein, H. S. R, R. G. Fairbanks and D. R. Zylberberg (2008),

494 Oscillating glacial northern and southern deep water formation from combined

495 neodymium and carbon isotopes, Earth Planet. Sci. Lett., 272(1-2), 394-405,

496 doi:10.1016/j.eps1.2008.05.011.

497 Pisias, N. G., P. U. Clark and E. J. Brook (2010), Modes of Global Climate Variability

498 during Marine Isotope Stage 3 (60 ka), J. Clim., 23(6), 1581-1588,

499 doi:10.1175/2009JCLI3416.1.

500 Rahmstorf, S. (2003), Timing of abrupt climate change: A precise clock, Geophys. Res.

$501 \quad$ Lett., 30(10), 1510, doi:10.1029/2003g1017115.

502 Rasmussen, T. L., D. W. Oppo, E. Thomsen and S. J. Lehman (2003), Deep sea records

503 from the southeast Labrador Sea: Ocean circulation changes and ice-rafting events

504 during the last 160,000 years, Paleoceanography, 18(1), 1018,

505 doi:10.1029/2001pa000736. 
506 Rasmussen, T. L., and E. Thomsen (2004), The role of the North Atlantic Drift in the

507 millennial timescale glacial climate fluctuations, Palaeogeogr., Palaeoclim.,

$508 \quad$ Palaeoecol., 210(1), 101-116, doi:10.1016/j.palaeo.2004.04.005.

509 Rasmussen, T. L., E. Thomsen, T. C. E. van Weering and L. Labeyrie (1996), Rapid

510 Changes in Surface and Deep Water Conditions at the Faeroe Margin During the Last

$511 \quad 58,000$ Years, Paleoceanography, 11(6), 757-771, doi:10.1029/96pa02618.

512 Schmittner, A., and E. D. Galbraith (2008), Glacial greenhouse-gas fluctuations

513 controlled by ocean circulation changes, Nature, 456(7220), 373-376,

514 doi:10.1038/nature07531.

515 Schulz, M. (2002), On the 1470-year pacing of Dansgaard-Oeschger warm events,

$516 \quad$ Paleoceanography, 17(2), 1014, doi:10.1029/2000pa000571.

517 Severinghaus, J. P., T. Sowers, E. J. Brook, R. B. Alley and M. L. Bender (1998), Timing

518 of abrupt climate change at the end of the Younger Dryas interval from thermally

519 fractionated gases in polar ice, Nature, 391(6663), 141-146, doi:10.1038/34346.

520 Shackleton, N. J., M. A. Hall and E. Vincent (2000), Phase Relationships Between

521 Millennial-Scale Events 64,000-24,000 Years Ago, Paleoceanography, 15(6), 565-

$522 \quad 569$, doi:10.1029/2000pa000513.

523 Shaffer, G., S. M. Olsen and C. J. Bjerrum (2004), Ocean subsurface warming as a

524 mechanism for coupling Dansgaard-Oeschger climate cycles and ice-rafting events,

$525 \quad$ Geophys. Res. Lett., 31(24), L24202, doi:10.1029/2004g1020968.

526 Steffensen, J. r. P., K. K. Andersen, M. Bigler, H. B. Clausen, D. Dahl-Jensen, H.

527 Fischer, K. Goto-Azuma, M. Hansson, S. s. J. Johnsen, J. Jouzel, V. r. Masson-

528 Delmotte, T. Popp, S. O. Rasmussen, R. Röthlisberger, U. Ruth, B. Stauffer, M.-L. 
Siggaard-Andersen, Á. E. Sveinbjörnsdóttir, A. Svensson and J. W. C. White (2008),

530 High-Resolution Greenland Ice Core Data Show Abrupt Climate Change Happens in

$531 \quad$ Few Years, Science, 321(5889), 680-684, doi:10.1126/science.1157707.

532 Stokes, C. R., and C. D. Clark (2001), Palaeo-ice streams, Quat. Sci. Rev., 20(13), 1437-

533 1457, doi:10.1016/s0277-3791(01)00003-8.

534 Svendsen, J. I., H. Alexanderson, V. I. Astakhov, I. Demidov, J. A. Dowdeswell, S.

535 Funder, V. Gataullin, M. Henriksen, C. Hjort, M. Houmark-Nielsen, H. W.

536 Hubberten, O. Ingolfsson, M. Jacobsson, K. Kjaer, E. Larsen, H. Lokrantz, J. P.

537 Lunkka, A. Lysa, J. Mangerud, A. Matioushkov, A. Murray, P. Möller, F. Niessen, O.

538 Nikolskaya, L. Polyak, M. Saarnisto, C. Siegert, M. J. Siegert, R. F. Spielhagen and

539 R. Stein (2004), Late Quaternary ice sheet history of northern Eurasia, Quat. Sci.

$540 \quad$ Rev., 23 (11-13), 1229-1271, doi:10.1016/j.quascirev.2003.12.008.

541 Svensson, A., K. K. Andersen, M. Bigler, H. B. Clausen, D. Dahl-Jensen, S. M. Davies,

542 S. J. Johnsen, R. Muscheler, F. Parrenin, S. O. Rasmussen, R. Rothlisberger, I.

543 Seierstad, J. P. Steffensen and B. M. Vinther (2008), A 60,000 year Greenland

544 stratigraphic ice core chronology, Clim. Past, 4(1), 47-57, doi:10.5194/cp-4-47-2008.

545 Taylor, K. C., C. U. Hammer, R. B. Alley, H. B. Clausen, D. Dahl-Jensen, A. J. Gow, N.

546 S. Gundestrup, J. Kipfstuh, J. C. Moore and E. D. Waddington (1993b), Electrical

547 conductivity measurements from the GISP2 and GRIP Greenland ice cores, Nature,

$548 \quad 366(6455), 549-552$, doi:10.1038/366549a0.

549 Taylor, K. C., G. W. Lamorey, G. A. Doyle, R. B. Alley, P. M. Grootes, P. A. Mayewski,

550 J. W. C. White and L. K. Barlow (1993a), The Flickering Switch of Late Pleistocene

551 Climate Change, Nature, 361(6411), 432-436, doi:10.1038/361432a0. 
552 Thomas, E. R., E. W. Wolff, R. Mulvaney, S. J. Johnsen, J. P. Steffensen and C.

553 Arrowsmith (2009), Anatomy of a Dansgaard-Oeschger warming transition: High-

554 resolution analysis of the North Greenland Ice Core Project ice core, J. Geophys.

555 Res., 114(D8), D08102, doi:10.1029/2008jd011215.

556 van Kreveld, S., M. Sarnthein, H. Erlenkeuser, P. Grootes, S. Jung, M. J. Nadeau, U.

557 Pflaumann and A. Voelker (2000), Potential links between surging ice sheets,

558 circulation changes, and the Dansgaard-Oeschger cycles in the Irminger Sea, 60-18

559 kyr, Paleoceanography, 15(4), 425-442, doi:10.1029/1999PA000464.

560 Voelker, A. H. L. (2002), Global distribution of centennial-scale records for Marine

561 Isotope Stage (MIS) 3: a database, Quat. Sci. Rev., 21(10), 1185-1212,

562 doi:10.1016/S0277-3791(01)00139-1.

563 Voelker, A. H. L., M. Sarnthein, P. M. Grootes, H. Erlenkeuser, C. Laj, A. Mazaud, M. J.

564 Nadeau and M. Schleicher (1998), Correlation of marine C-14 ages from the Nordic

565 Seas with the GISP2 isotope record: Implications for C-14 calibration beyond $25 \mathrm{ka}$

566 BP, Radiocarbon, 40(1), 517-534.

567 Vorren, T. O., et al. (1998), The Norwegian-Greenland Sea Continental Margins:

568 Morphology and Late Quaternary Sedimentary Processes and Environment, Quat.

569 Sci. Rev., 17(1-3), 273-302, doi:10.1016/S0277-3791(97)00072-3.

570 Walker, R. T., T. K. Dupont, D. M. Holland, B. R. Parizek and R. B. Alley (2009), Initial

571 effects of oceanic warming on a coupled ocean-ice shelf-ice stream system, Earth and

$572 \quad$ Planet. Sci. Lett., 287(3-4), 483-487, doi:10.1016/j.eps1.2009.08.032.

573 Weber, M. E., L. A. Mayer, C. Hillaire-Marcel, G. Bilodeau, F. Rack, R. N. Hiscott, and

574 A. E. Aksu (2001), Derivation of $\delta^{18}$ O from Sediment Core Log Data: Implications 
575 for Millennial-Scale Climate Change in the Labrador Sea, Paleoceanography, 16(5),

$576 \quad 503-514$, doi:10.1029/2000PA000560.

577 Winton, M. (1993), Deep Decoupling Oscillations of the Oceanic Thermohaline

578 Circulation, in Ice in the Climate System, edited by W. R. Peltier, pp. 417-432,

579 Springer-Verlag, New York.

580 Wolff, E. W., J. Chappellaz, T. Blunier, S. O. Rasmussen and A. Svensson (2010),

581 Millennial-scale variability during the last glacial: The ice core record, Quat. Sci.

582 Rev., 29(21-22), 2828-2838, doi:10.1016/j.quascirev.2009.10.013.

583 Wunsch, C. (2000), On Sharp Spectral Lines in the Climate Record and the Millennial

584 Peak, Paleoceanography, 15(4), 417-424, doi: 10.1029/1999pa000468.

585 Zahn, R., J. Schönfeld, H.-R. Kudrass, M.-H. Park, H. Erlenkeuser and P. Grootes

586 (1997), Thermohaline Instability in the North Atlantic During Meltwater Events:

587 Stable Isotope and Ice-Rafted Detritus Records from Core SO75-26KL, Portuguese

$588 \quad$ Margin, Paleoceanography, 12(5), 696-710, doi:10.1029/97pa00581.

$590 \quad$ Figure Captions

591

592 Figure 1. Multiple proxies showing DO variability in the Nordic Seas (B) compared to

593 Heinrich variability in the IRD belt (C). A. NGRIP $\delta^{18} \mathrm{O}_{\text {ice }}$ vs. age model GICC05

594 [Svensson et al., 2008] B. Planktonic $\delta^{18} \mathrm{O}$ (black line) and Lithic grain concentration

595 (\#/gram) (grey solid) vs. age model from core PS2644-5 [Voelker et al., 1998] C.

596 Planktonic $\delta^{18} \mathrm{O}$ (black line), >125um size fraction (\%) (dotted line), and Percent

597 carbonate (\%) (grey solid) vs. age from core MD95-2024 [Hillaire-Marcel and Bilodeau, 
598 2000; Weber et al., 2001] D. Map showing the location of the proxy records plotted in A-

599 C. Letters on the map correspond to subfigures.

600

601 Figure 2. Schematic of proposed DO oscillation mechanism. Phases of the DO cycle

602 labeled a-e with corresponding description of changes in cryosphere and Greenland

603 temperature occurring during each phase. 20-year resolution $\delta^{18} \mathrm{O}_{\text {ice }}$ from NGRIP ice core

604 (grey line) [Svensson et al., 2008] over the period 43-49 ka showing DO 12, with a 10-

605 point smoothing of the data (black line). 